\title{
Reflective Feedbacks and Project-Based Activities to Improve the Students' Writing Skill: an Exploratory Action Research
}

\author{
Nur Najibah Sukmawati ${ }^{1}$ \\ ${ }^{1}$ Universitas Pamulang, Pamulang - Indonesia \\ Email: dosen01859@unpam.ac.id \\ DOI: 10.18326/rgt.v13i2.315-332
}

Submission Track:

Received: 12-05-2020

Final Revision: 13-10-2020

Available Online: 01-12-2020

Copyright @ 2020 Nur Najibah Sukmawati

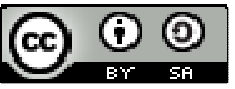

This work is licensed under a Creative Commons Attribution-ShareAlike 4.0 International License.

\begin{abstract}
Teaching writing to Informatics Engineering students has its uniqueness when it comes to what specific issue(s) the students are facing and how to cope with them. This study aims at finding out some feedback for the author's previous teaching practices in writing a descriptive text which becomes the basis to give an exact intervention as well as to find out whether the intervention is able to improve the students' skill in writing a descriptive text. This is an exploratory action research to the 30 students of the third semester in Informatics Engineering study program of a private university in Indonesia. To gain feedback on the previous instructional practices, a senior colleague is invited as a consultant and an openended questionnaire was distributed to the students. Some issues were found. After a deep discussion with the senior colleague, it is concluded that project-based activities could cope with the issues. To prove it, a writing test and open-ended interview were conducted. During the instructional practices, a collaborator was invited to observe using an observation sheet. The result revealed that project-based activities engaged the students and directed them in accomplishing the task. The test also showed improvement in students' average score. These findings proved that implementing project-based activities can improve the students' skill in writing a descriptive text.
\end{abstract}

Keywords: exploratory action research; reflective feedbacks; project-based activities 


\section{INTRODUCTION}

Teaching English for specific purposes has come to a trend that classroom activities are directed to involve students' active participation (Kember, 2009; Attard, Di Iorio, Geven, \& Santa, 2010). Classroom is manipulated to represent real life and students are a community representative. Moreover, all activities must be oriented to sharpen the skills needed to survive with the rapid change of living in the 21st century. Accordingly, education practitioners are demanded to modify activities that make students' role significant in the instructional process.

In contrast, implementing this teaching trend is not supported with gauging the impact to students' achievement. Some problems faced by ESP practitioners are their learners being likely to have below-average language proficiency (Ibrahim, 2010; Robinson, 2013) due to the failure of learning at the secondary level (Unal, Sadoglu \& Urukan, 2014) as well as a low motivation for being proficient assuming that it is irrelevant with their future (Wahyudin, 2017). These factors cause some difficulties in performing English proficiency, which is generally measured through language skills traditionally sequenced as listening, speaking, reading, and writing.

Amid technology savvies, writing skill maintains its popularity where written information, transaction and communication take higher frequency than oral ones in use. Electronic sources of information such as e-magazine, or e-newspaper, of transaction such as online payment, as well as communication such as social media platforms take the advantage of written forms. On the other hand, the teaching of writing has come to a lean on process rather than product-based approach through a series of steps that signifies students' ability to explore and define their own problems in writing. The mainstream of writing process does not only acquire students to eventually come with their products. It is also directed to enhance students' life skills that are useful for their future.

In the Informatics Engineering study program, teaching writing is aimed at enabling the students to express their own thought to their community (Richard, 2015) such as explaining the concept of data, procedures in operating new technology products, describing newly-released technology products, and others. This technology-related context is integrated within linguistic components as a medium to deliver meaning. Therefore, writing is considered a very 
complex cognitive activity (Shirzadi \& Amerian, 2020) that requires continuous and guided practices to achieve good results. In short, the writing skill is considered difficult to practice. Accordingly, pedagogical reactions towards the status quo should be vehement. This study is aimed at exploring what teaching method is best implemented to teach my students' writing skill and whether the teaching method can improve the students' skill in writing a descriptive text.

Exploration to the real situation is necessary to know what intervention to do. Afterward, the intervention should also be evaluated to the extent to its effectiveness in coping with the students' problem in learning. Such a study is called exploratory action research, which has become popular to conduct in countries where English is taught/learned as a foreign language.

An exploratory action research was conducted by Meneses (in Smith \& Rebolledo, 2018) who seeks the possibility to improve her students' participation and inclusion in her English class. It was initiated because her 28 students performed low engagement to the instructional practices so she delved into dimensional perspectives for the cause by creating three different questionnaires for her colleagues, for her students, and for her own critical reflections. The questionnaires gave her ideas to introduce more interactive and fun activities using a teaching medium to review vocabulary, miming, memory games, project work, and group competitions. After implementing those teaching strategies, it was found that her students' participation improved.

Another exploratory action research was conducted by Aguilera (in Smith and Rebolledo, 2018) in her English class of 35 students of senior high school. She found that among the four skills, many students lost points in the writing section. Then, she started by an informal chat with nine other subject teachers to have an idea about the way they teach writing. Next, she asked her coordinator to observe her teaching. And after the lesson, she led a plenary discussion with her students to find out whether the lesson had been helpful. And finally, she interviewed the students whose grades were lower because she felt they could offer further insights. This exploration earns a conclusion that she was unaware of her own role in their learning and better understands the expression 'teaching-learning process.' Accordingly, she planned some actions 
to do: (1) considering her students' age and interests when choosing topics; (2) considering the quality of the input she gives and the feedback she provides while they are writing; (3) taking into account the learners' pace so they can complete the task successfully before moving on to another; and (4) allowing more opportunities for practice. 2 cycles of treatment came up with a finding that her students' writing skill improved.

A classroom action research was conducted by Vera Maria Shanti, Syahrial, and Irwan Koto (2016), in a state senior high school in South Bengkulu, Indonesia. Conducted in two cycles, this study aims at finding out whether Project-based learning can improve the students' skill in writing a descriptive text. Using a writing test, observation and teacher's checklist, and interview, this study found that implementing project-based learning can improve the students' skill in writing a descriptive text. Additionally, this study, published in Journal of Applied Linguistics and Literature, also emphasized that one of the steps called 'monitoring the students' progress' gave the most significant contribution so the students' average score reached (80.31) or improved about 9 points from the previous test.

The related studies are in the same context with my study that we attempted to improve the students' skill. The first two used exploratory action research but they focus on minor skills and are contextualized in general English while my study focus on major skill is contextualized in English for specific purpose. The last one focuses on improving the students' skill in writing a descriptive text, which is also the main limitation of this study but the authors use action research, which does not come with any reason why project-based activities are used.

Though it is popular in EFL countries, exploratory action research has not yet emerged in Indonesia. Exploratory action research comes with the idea of emphasizing the urgency of delving into the exact causes teachers and students are facing in their instructional practices to generate the appropriate intervention to give and to put emphasis on finding out whether the intervention is effective without gauging whether the intervention is what the students actually need. A critique is given to the mainstream of classroom action research that treatment, which was aimed to solve the problem, is 
potentially not the one needed to solve. It is what Smith and Rebollledo (2018) wrote in their newly published handbook for exploratory action research published by British Council that put the significance of exploration before treatment in order to come up with the exact solution to improve students' achievement at either the micro or macro level. This reason is plausible so every teacher knows what to do to improve their students' skill. Accordingly, this is novel that exploratory action research should be conducted especially when it is situated in English for specific purpose context.

\section{RESEARCH METHOD}

This is an exploratory action research that aims to explore, understand, and improve the lecturer's practices in teaching writing for Informatics Engineering students. According to Smith and Rebolledo (2018), exploratory action research is initially designed to criticize teacher researchers who frequently take too-quick decision, lack exploring the situation further, and base it on signs and intuition in improving students' achievement. Exploratory action research puts attention to exploring why the situation is happening, as can be explored through the collection of data, and how to solve it. The step in implementing the exploratory action research is portrayed in Figure 1.

The exploration stage was commenced by reviewing my practice in teaching writing by thinking about the questions that students need to answer and plan how to explore information to answer my questions. Then, some data were collected to clarify the situation to be analyzed and interpreted. The result of analysis is used to reflect on what has happened. This reflection is used as the basis to make an action plan.

On the action stage, after deciding to change the teaching method and design a lesson plan to be implemented in teaching a descriptive text, a plan was designed. The next step is to apply the lesson plan. During and after the intervention takes place, the instructional practices were observed by a collaborator that became the basis to be interpreted as a reflection and consideration for further actions that seem necessary. 


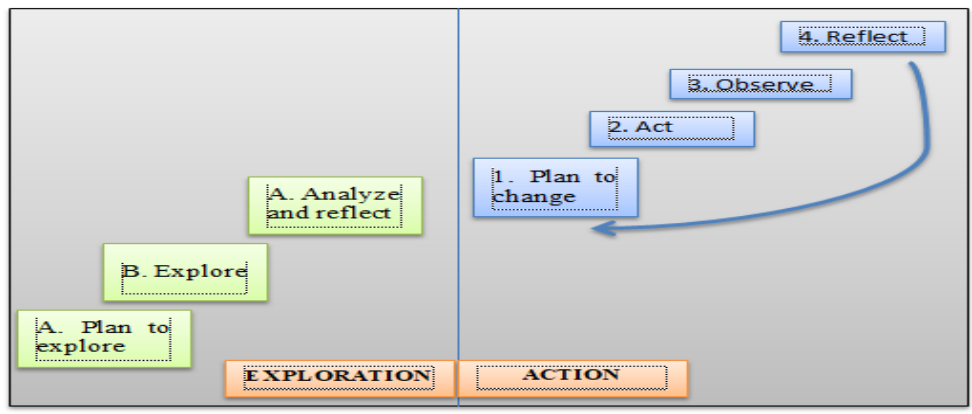

Figure 1. Exploratory Action Research Designed by Smith and Rebolledo (2018)

\section{Participants}

The participants of this study consisted of 30 students of the Informatics Engineering study program who were undertaking English-for-InformaticsEngineering Class. The students' demographics were similar in terms of age but has with slightly different proficiency levels in writing a descriptive text as shown in Table 1.

Table 1 also depicts that the students were quite various in terms of the result of their pre-test writing score. It can be seen that two thirds of the students obtained 50 to 60 which means they have sufficient writing skills but are limited in vocabulary, perform many mistakes in grammar though still understood, could not develop their ides more specifically, and made improper cohesive devices. A few of them were workers and performed different writing skill with 1 of them obtained score 60-70.

Table 1. Identity of the Object of the Study

\begin{tabular}{ccccccc}
\hline \multirow{2}{*}{$\begin{array}{c}\text { Range of Score } \\
\text { Obtained }\end{array}$} & $\begin{array}{c}\text { Number of } \\
\text { students }\end{array}$ & & \multicolumn{2}{c}{ Gender } & & \multicolumn{2}{c}{ Profession } \\
\cline { 3 - 4 } \cline { 6 - 7 } \cline { 6 - 7 } & & Male & Female & & Student & Student Worker \\
\hline $40-50$ & 5 & 5 & 0 & & 3 & 2 \\
$50-60$ & 20 & 17 & 3 & & 18 & 2 \\
$60-70$ & 4 & 2 & 2 & & 3 & 1 \\
$70-80$ & 1 & 0 & 1 & & 1 & 0 \\
\hline
\end{tabular}




\section{Instruments}

\section{Open-ended questionnaire}

Open ended questionnaire was used in exploring the instructional situation by formulated questions given to my students as well as in observing the effect of the intervention to the students. The questionnaire was chosen for students because it can delve into their perception more in written form without their names being noticed (Smith and Rebolledo, 2018), Both questionnaires are shown in Table 2.

\section{Testing and Assessing}

In order to find out whether the students' skill in writing a descriptive text improve after they learn using project-based activities, an instructional writing test is designed. The students were asked to compose a descriptive text about information technology and their composition is assessed by using the rubric shown in Table 3.

Table 2. The Questionnaires

\begin{tabular}{ll}
\hline Questionnaire in Exploration Stage & Questionnaire in Action Stage \\
\hline $\begin{array}{l}\text { Did you find the previous learning } \\
\text { activities effective in boosting your }\end{array}$ & $\begin{array}{l}\text { What do you think about current learning } \\
\text { activities? }\end{array}$ \\
$\begin{array}{l}\text { Mriting skill? } \\
\text { Mention specifically the drawbacks of the }\end{array}$ & $\begin{array}{l}\text { Do you find the activities effective in } \\
\text { poosting your writing skill? }\end{array}$ \\
$\begin{array}{l}\text { Mention specifically the strengths of the } \\
\text { previous writing activities. }\end{array}$ & $\begin{array}{l}\text { Do you think your writing skill improves } \\
\text { after doing the activities? }\end{array}$ \\
$\begin{array}{l}\text { Mention specifically what activities you } \\
\text { wish to do in writing a text. }\end{array}$ & \\
\hline
\end{tabular}

Table 3. Writing Indicators

\begin{tabular}{|c|c|c|c|c|}
\hline No. & Indicators & Aspects & Description & $\begin{array}{l}\text { Range } \\
\text { Score }\end{array}$ \\
\hline \multirow[t]{5}{*}{1.} & Content & Unsatisfying & $\begin{array}{l}\text { Not complete and difficult to } \\
\text { understand }\end{array}$ & $0-4$ \\
\hline & & Fair. & Provide quite intelligible explanation & $5-8$ \\
\hline & & Good & Provide fairly-intelligible explanation & $9-12$ \\
\hline & & Very Good & Provide intelligible explanation & $13-16$ \\
\hline & & Excellent & $\begin{array}{l}\text { Provide strongly intelligible } \\
\text { explanation }\end{array}$ & $17-20$ \\
\hline
\end{tabular}




\begin{tabular}{|c|c|c|c|c|}
\hline \multirow[t]{3}{*}{2.} & Organization & Unsatisfying & $\begin{array}{l}\text { Lack organization, and does not } \\
\text { utilize any transitional } \\
\text { words/phrases, Ideas disconnected, } \\
\text { lack transitional words/phrases } \\
\text { Loosely organized but main ideas } \\
\text { understood, incomplete but logical } \\
\text { transitional words/phrases }\end{array}$ & $\begin{array}{l}5-8 \\
9-12\end{array}$ \\
\hline & & Very Good & $\begin{array}{l}\text { Fairly well organize and use effective } \\
\text { transitional words/phrases }\end{array}$ & $13-16$ \\
\hline & & Excellent & $\begin{array}{l}\text { Well organized and use effective } \\
\text { transitional words/phrases }\end{array}$ & $17-20$ \\
\hline \multirow[t]{5}{*}{3.} & Grammar & Unsatisfying & $\begin{array}{l}\text { Unsatisfying Errors in grammar are } \\
\text { frequent but the text can be } \\
\text { understood }\end{array}$ & $0-4$ \\
\hline & & Fair. & $\begin{array}{l}\text { Can frequently handle basic } \\
\text { constructions quite accurately but } \\
\text { doesn't have consistent control of the } \\
\text { grammar. }\end{array}$ & $5-8$ \\
\hline & & Good & $\begin{array}{l}\text { Grammar control is good. Able to } \\
\text { write the language with fair structural } \\
\text { accuracy }\end{array}$ & $9-12$ \\
\hline & & Very Good & $\begin{array}{l}\text { Almost no errors in grammar and } \\
\text { consistent in structural accuracy. }\end{array}$ & $13-16$ \\
\hline & & Excellent & $\begin{array}{l}\text { Excellent Equivalent to that of an } \\
\text { educated native writer }\end{array}$ & $17-20$ \\
\hline \multirow[t]{5}{*}{4.} & Vocabulary & Unsatisfying & $\begin{array}{l}\text { Very limited or poor range, very } \\
\text { limited knowledge of words and } \\
\text { words forms }\end{array}$ & $0-4$ \\
\hline & & Fair & $\begin{array}{l}\text { Limited range, confused use of words } \\
\text { and words forms }\end{array}$ & $5-8$ \\
\hline & & Good & $\begin{array}{l}\text { sufficient choice of words but some } \\
\text { misuse of words forms and } \\
\text { vocabularies }\end{array}$ & $9-12$ \\
\hline & & Very Good & $\begin{array}{l}\text { Effective choice of words and words } \\
\text { forms }\end{array}$ & $13-16$ \\
\hline & & Excellent & $\begin{array}{l}\text { Very effective choice of words and } \\
\text { words form }\end{array}$ & $17-20$ \\
\hline \multirow[t]{4}{*}{5.} & Mechanic & Unsatisfying & $\begin{array}{l}\text { No mastery of convention, dominated } \\
\text { by errors of punctuation: periods, } \\
\text { commas, semicolons, quotations, and } \\
\text { marks and initial capital letters }\end{array}$ & $0-4$ \\
\hline & & Fair. & $\begin{array}{l}\text { Frequent errors of punctuation: } \\
\text { periods, quotation, semi colons, } \\
\text { commas, and marks. }\end{array}$ & $5-8$ \\
\hline & & Good & $\begin{array}{l}\text { Occasional errors of punctuation: } \\
\text { periods, quotation, semi colons, } \\
\text { commas, and marks. }\end{array}$ & $9-12$ \\
\hline & & Very Good & Well organized and utilize & $13-16$ \\
\hline
\end{tabular}


punctuation: periods, quotation, semi colons, commas, and marks.

Excellent Well organized and utilize punctuation: periods, quotation, semi colons, commas, and marks.

Final Score $\Sigma$ each indicator

\section{FINDING \& DISCUSSION}

As a reflective teacher, I base my decision on conducting an exploratory action research from a test in a pre-survey on the students' skill in writing a descriptive text. An instructional test to compose a descriptive text of 200 words was given. Then, their composition was assessed using the rubric scoring attached in Table 3. The assessment was overall a reflection that some drawbacks were found in their paper test most of which deals with grammatical mistakes. Many students committed subject-verb agreement errors in their texts. Another common drawback is incoherence, which made their idea wrongly delivered. However, they were good at vocabulary related to describing computer-related materials. This pre-treatment finding was a reason that obtaining average score 54.96 was enough to necessarily explore the students' problems in writing a descriptive text.

\section{Exploration Stage}

The exploration stage aims at exploring the real situation as well as reflecting previous instructional practices in order to determine the most feasible intervention to the students in the action stage (Smith \& Rebolledo, 2018). Accordingly, some insight was gathered by consulting with my senior colleague and distributing questionnaires to the students.

For more insight on the result of pre-treatment test, it was forwarded to the senior colleague who had, by then, been teaching English for the Informatics Engineering study program for more than 10 years. She addressed some questions to reflect what I had done so far in teaching them writing in order to focus on and limit the issue I was facing. She started her questions by inquiring about my interaction with the students. Then, it became more specific to what teaching method was used in teaching them writing and how students' engagement was in general. This discussion ended with some notes to 
highlight: (1) I put students as the center of the writing process but did not perform a formulaic strategy in facilitating the activities; (2) I focused on the students' writing process but paid less attention to their engagement to the process; (3) information-exchange and intrapersonal interaction amongst students were very little and collaboration only happened to accomplish the assignment. This reflection elucidated that I needed to focus on evaluating my method in teaching them writing because all the mentioned factors conclude that the instructional activities did not engage the students and to perform clearer steps in running the instructional process is necessarily needed.

Then, a set of questionnaires was formulated for students to reveal their perception towards the instructional practices used. The items are depicted in Table 4. The students' responses to the items: (1) 45\% of the students agree that the previous learning activities are fairly effective. Only 15 of them found it effective and $40 \%$ thought that it was not effective. It is because of (2) some drawbacks like the activities being not well-organized where students were given the opportunity to work on the assignment leading to confusion. The students found it difficult to autonomously understand the mechanism of writing a text. However (3) some strengths to highlight were deemed fun by the students to collaborate and cooperate with their friends, and they actualized themselves more by working in a small group. The last item (4) concluded that some activities they wished to do in writing are lecturers explaining some examples of composing a text as well as linguistic-related materials. They also want their writing project to be given some reinforcement and feedback from the lecturers.

These findings, from both my senior colleague and students, are a basis to decide what intervention to give. After a deep consultation with my colleague and analyzing the results of the questionnaire, we ended up to deciding that it is the teaching method that should be different. The method needed is the one that covers the students' needs in learning: (1) collaboration among the students within a small group so they can interchange or share one to each other; (2) comprehensive explanation and student' exposure to the linguistic components of the text; (3) well-directed activities so they are confident that they are doing everything right. Accordingly, we decided to conduct project- 
based activities. This teaching method is popular in constructivism era, which encourages students to create their own concepts and beliefs toward knowledge (Weegar \& Pacis, 2012) and the teacher provides opportunities for collaborative activities and authentic tasks (Nasution \& Sukmawati, 2019). Project-based activities as one of teaching methods in constructivism that bring some principles to the instructional process. It directed students to work around projects (Thomas, 2000; Larmer, Markham, \& Ravitz, 2003; Bell, 2010), which can raise students' motivation by being fully involved and engaged in the classroom activities. It directed students to plan, implement, reflect, and evaluate their own learning by working on authentic tasks (Blank in Blank \& Harwell, 1997; Dickinson, et al., 1998; Westwood, 2008), so they could still feel the nuance of independence yet directed activities. This also promotes students through sharing information, discussing the project, dividing tasks on each group member, and presenting the project result (Guven, 2014) as they wish that they and I could mingle and share information and the nuance of collaborative learning remains there.

Project-based learning is generally a social practice into which learners socialize through a series of group activities (Mali, 2017) that provide learners with opportunities to solve a problem and learn from each other as they coconstruct knowledge (Whatley, 2012) by doing a project. Simultaneously, this can encourage them to be autonomous learners capable of taking responsibility for their own learning (Richards, 2015).

The implementation of project-based learning is not rigid and therefore can be modified based on learning situation. Referring to Stoller (1997), Korkmaz \& Kaptan (2001), project-based learning starts with (1) a teacher and learners negotiating a topic of the project and method of solving the problem; (2) learners are given space to design the project by inquiring into information related to the project, the plan, and the objective of the project; (3) learners gather, analyzed and organized data to answer the problems or the tasks. The project is based on the application of the knowledge they achieve through the process of inquiring; (4) learners define the essential point of the project; (5) learners plan the presentation method; (6) learners design the presentation from the result of analysis and compile the essential information about the 
project; (7) learners present their project; (8) learners evaluate the overall learning process.

\section{Activities in and Improvement after Cycle 1}

To start the study, a senior colleague was invited to collaborate as a mentor, observer, and evaluator. We first planned a set of lesson plans during the first cycle based on the findings in the exploration stage as well as the students' result in pre-test. It is decided that the lesson plan was based on steps suggested in project-based activities.

There were some findings to reveal after conducting 4 meetings. First, it was observed that the students were enthusiastic when it came to the negotiation process on what topic to explain. Initially, they thought that the explanation text focused on a general topic such as explaining things surrounding them, but when they were informed to explain things related to computers, they became enthusiastic as it features in their interest. However, when it came to setting their goal and target, they became confused because they had never been assigned to be autonomous and independent in planning activities to compose the text. Most of them decided to use internet-based assistance to gather data. Some other chose to directly open their computer and conduct an in-depth analysis related to the topic. However, they could not go consistently with the plan. Many of them became passive during group activities. The observation sheet also reveals that some students choosing to use internet-based assistant deviated from the purpose by engaging in social media or other irrelevant activities. In the next meeting, they started to compose a text based on results of discussion in the previous activities, but another problem was found. They were challenged in linguistic matters such as chaining sentences coherently, and committing less grammatical mistakes. My collaborator suggested that grammar-based expository was needed to conduct so they could minimize the mistake. Consequently, when it came to the group presentation session, the active students dominated the activity. However, some strength in project-based activities was found. It allowed them to be open to questions and answers. The information exchange happened and the fun atmosphere was captured. At the end of the cycle, a test was conducted and it was found that the students' average score improved to 58.65 . 


\section{Activities in and Improvement after Cycle $\mathbf{2}$}

Findings from activities in cycle 1 concluded that the average score the students obtained was still low, and the observation sheet also revealed some problems to solve. It is in line with Walker (2001) that the implementation has not been without some challenges such as interpersonal conflicts and unequal distributions of workload among the group members. Accordingly, cycle 2 was conducted. A plan was redesigned to reach learning quality assurance and to anticipate drawbacks that happened in cycle 1 . We decided to focus more on the linguistic features of the text and on implementing a teaching strategy that engages the students' participation to mitigate the conflict as two major drawbacks found in cycle 1 . Accordingly, teaching activities were oriented to empower the students' linguistic mastery, especially in composing complex sentences, and chaining ideas more coherently in order to produce a better text. After that, the students were assigned to work in a small group doing the same project with different topic. They chose to explain the current topic on informatics engineering like big data, Internet of things (IoF), and social networking. To avoid students' disengagement during gathering and analyzing data, I assigned each of them to submit a one-page individual report on their personal contribution during the discussion process. This was evidently a success to boost their learning awareness in the group discussion. It can be seen from the result of the observation that many students became more aware of their contribution to the learning practice. In the presentation step, many groups could compose a better writing project that better suits the nature of an explanation text. At the end, a final test to the students' writing skill was an evidence of improvement where the average score reached 71.3. The students' average scores from Pre-Cycle, Cycle 1, and Cycle 2 is portrayed in Table 4.

Table 4. The Students' Average Scores in Pre-Cycle, Cycle 1, and Cycle 2.

\begin{tabular}{lll}
\hline Pre-Cycle & Cycle 1 & Cycle 2 \\
\hline 54.96 & 58.65 & 71.3 \\
\hline
\end{tabular}

During the implementation, project-based activities were evident in encouraging the students' participation as they were given an equal responsibility to cope with the project. They showed enthusiasm when working 
with their classmates. It gave them more confidence to exchange information. They also found that writing a text cooperatively is feasible to do. The steps offered in project-based activities directed them to finish the task sequentially and it eased them to do so as stated by Student 1 :

Now, our learning activities were more directed. We know how to accomplish the task given to our group because our lecturer instructed me to do observation first in order we have insight what to write. I think it is good and new to me that preparation before action is necessary in writing.

Student 2, in his commentary speech, thought that reading a lot before writing is actually to help him in accomplishing the task:

I thought that writing is writing. All you need to do is just write. But my lecturer directed us to collect all data related to the thing we will describe. I found this step essential.

Student 3 highlighted the evaluation step as a meaningful activity to improve their writing skill:

When our group thinks that we already did our best in writing descriptive text. It was actually a text full of revision. Other groups could reveal what to revise and that was insightful for our better text. Two heads are really better than one.

On the other hand, my senior colleague also agreed that the students' engagement in the project is good and that the activities made them responsible toward the task given to them. In addition, the students were fond of experiencing a series of steps that directed them to accomplish the task. It could be seen from their enthusiasm about sharing and asking within their group and asking for my validation when needed. Supported by the finding from the students' improving average score, it can be concluded that implementing project-based activities can improve the students' skill in writing a descriptive text. This finding is in line with some studies from Simuwardani, Nuryatin, and Doyin (2019), and Shanti, Syahrial, and Koto (2016) that project-based activities are effective to be implemented to improve students' skill in writing.

\section{CONCLUSION}

Teaching English for specific purposes follows the trend that it aims at bracing the students to survive in the 21st century. Accordingly, instructional 
practices should be under a method that encourages them to be autonomous, independent, cooperative, and collaborative. Project-based activities are evident in accommodating the skills and are relevant in teaching writing to informatics engineering students. Along with the process, the students could perform more engaging and collaborative learning activities to actualize and sharpen their skill in writing, which is proven by the improvement of their average score in writing a descriptive text. This study ends with a recommendation that to improve the students' achievement, we need to be open for input from many perspectives and parties in order to know and decide the best intervention to consider. This is a significant part to come with a treatment that students actually need.[rgt]

\section{REFERENCES}

Attard, A., Di Iorio, E., Geven, K., \& Santa, R. (2010). Student-centered learning: toolkit for students, staff and higher education institutions. Bucharest: European Students' Union (NJ1).

Blank, W. E., \& Harwell, S. (1997). Promising practices for connecting high school to the real world. Tampa, FL: University of South Florida, 15-21.

Bell, S. (2010). Project-based learning for the 21st century: Skills for the future. The Clearing House, 83(2), 39-43.

Dickinson, K. P., Soukamneuth, S., Yu, H. C., Kimball, M., D'amico, R., Perry, R.,\& Curan, S. P. (1998). Providing educational services in the Summer Youth Employment and Training Program. Technical assistance guide. http://www.eric.ed.gov/PDFS/ED420756.pdf (accessed 27/9/2016).

Guven, Z. Z. (2014). Project based learning: A constructive way toward learner autonomy. International Journal of Languages' Education and Teaching. Turkey: Necmettin Erbakan University Department of Linguistics.

Ibrahim, A. (2010). ESP at the tertiary level: Current situation, application and expectation. English Language Teaching 3, 200-204.

Ismuwardani, Z., Nuryatin, A., \& Doyin, M. (2019). Implementation of project based learning model to increased creativity and self-reliance of students on poetry writing skills. Journal of Primary Education, 8(1), 51-58. 
Kaptan, F., \& Korkmaz, H. (2001). Fen eğitiminde probleme dayalı öğrenme yaklaşımı. Hacettepe Üniversitesi Eğitim Fakültesi Dergisi 20, 185-192.

Kember, D. (2009). Promoting student-centred forms of learning across an entire university. Higher Education 58.1, 1-13.

Markham, T., Larmer, J., \& Ravitz, J. (2003). Project based learning handbook a guide to standards-focused pbl for middle and high school teachers. Buck Institute for Education (BIE).

Mali, Y. (2017). EFL students' experiences in learning call through project based instructions. TEFLIN Journal, 28(2), 170-192. http://dx.doi.org/10.15639/ teflinjournal.v28i2/170-192

Nasution, S., \& Sukmawati, N. (2019). Model United Nations: Improving the students' speaking skill.JEES (Journal of English Educators Society), 4(2), 4752. http://doi.org/10.21070/jees.v4i2.2100

Richards, J. C. (2015). Key issues in language teaching. Cambridge: Cambridge University Press. Seidman, A., \& Brown, S.C. (2006).

Robinson, J. K. (2013). Project-based learning: Improving student engagement and performance in the laboratory. Analytical and Bioanalytical Chemistry 405(1), 7-13.

Shanti, V. M., \& Koto, I. (2016). Project based learning approach to improve students 'ability to write descriptive text (A classroom action research at grade X SMAN I Bengkulu Selatan).JOALL (Journal of Applied Linguistics \& Literature), 1(2), 46-54.

Shirzadi, D. \& Amerian, M. (2020). Washback effects of multiple-choice, cloze, and metalinguistic tests on EFL students writing. Indonesian Journal of Applied Linguistics, 9, 536-544.ttp://doi.org/10.17509/ijal.v9i3.23203

Smith, R. \& Rebolledo, P. (2018). A handbook for exploratory action research. London: British Council

Stoller, F. L. (1997). Project work: A means to promote language content. English Teaching Forum 35.4, 2-16

Thomas, J. W. (2000). A review of research on project-based learning. California: The Autodesk Foundation.

Unal, S., Sadoglu, G. P., \& Durukan, U. G. (2014). Teacher educators' views of "model" concept and their mental models. Journal of Baltic Science Education, 13(5). 674-694 
Wahyudin, A. Y. (2016, November). The effect of project-based learning on L2 spoken performance of undergraduate students in English for business class. In Ninth International Conference on Applied Linguistics (CONAPLIN 9). Atlantis Press.

Whatley, J. (2012). Evaluation of a team project based learning module for developing employability skills. Informing Science and Information Technology, 9, 75-92.

Weegar, M. A., \& Pacis, D. (2012). A comparison of two theories of learningbehaviorism and constructivism as applied to face-to-face and online learning. Proceedings E-Leader Conference, Manila. https://www.gcasa.com/conferences/manila/ppt/Weegar.pdf (accessed 13/11/2016).

Westwood, P. S. (2008). What teachers need to know about teaching methods (Aust Council for ed research). Victoria: Acer Press. 
Nur Najibah Sukmawati

This page intentionally left blank. 